\title{
Evaluation of Character Implementation on Junior High School and Madrasah Tsanawiyah Students in Payakumbuh City
}

\author{
Aryadie Adnan $^{1(*)}$, Ishak Aziz ${ }^{1}$, Hendri Irawadi ${ }^{1}$ \\ ${ }^{1}$ Faculty of Sport Science, Universitas Negeri Padang, Indonesia \\ "Corresponding author. Email: aryadie@fik.unp.ac.id
}

\begin{abstract}
In junior high school of Payakumbuh, character education has been implemented through the integration of 18-character value, in 11 subjects and control by parents. The type of the research was Evaluative. The samples of this research were junior high school selected by using random sampling technique. In collecting the data researcher used documentary survey and questionnaires. In analyzing the data researcher used descriptive analysis and regression analysis to determine the effect of the character education program in the schools with students' attitudes and behaviors at home. From the data analysis obtained: the achievement of the implementation of character Education program conducted on each subject teacher obtained by $44,19 \%$ or categorized Very Low. The achievement of attitudes and behavior of the students through Moral Education program observed by parents at home is $51.44 \%$ or Low category. The correlation between character education program and the attitudes and behavior of students, is not significant.
\end{abstract}

\section{Keywords: Character, Behavioral Education}

\section{INTRODUCTION}

The advancement of IT has made the part of the world unlimited, especially in terms of information. ThroughIT,people spreadboth positive and negative information. This will certainly have an effect on the development of students' character,there are many negative impacts such as crime of adolescence, drugs, violence, promiscuity. In the National RPJM 2014 - 2019 President Jokowi has set Nawa Cita for the nation development within the next 5 years, the eighth point of Nawa Cita is "Revolutionary character of the nation through rearranging the policy of the national education curriculum by prioritizing the aspect of civic education which put proportionally educational aspect, such as teaching history onhow to form the nation, the value of patriotism and love of the country, the spirit of state defenses and characteristics in the education curriculum of Indonesia ".Based on the above conditions Payakumbuh Government through POKJA Jarlit Payakumbuh team, want to evaluate the implementation of character education activities that have been done in SMP and MTs Payakumbuh for the last 3 years. From some explanations on the above background, can be formulated this research problem is: How is the achievment of character educational activities conducted for studentsin SMP and MTs Payakumbuh?; How is the achievement of Akhlak Mulia educational activities in the attitude and children's behaviordaily.
Based on the background and the formulation of the problem, the aims of this research are : To know the achievement of the character educational program by teachers on Junior High School and MTs students in Payakumbuh; To know the achievement of students' attitude and behavior in family and environment in daily life.

Literally the evaluation comes from an English word evaluation which means assessment or appraisal. Defines evaluation as "The process of delineating, obtaining and providing useful information for judging decision alternatives". [1]. This means that evaluation is a process of describing, obtaining and presenting useful information to formulate an alternative decision. Evaluation is "an assessment of data collected through assessment activities. Meanwhile" [2]. Evaluation is a decision on value based on measurement results. In line with this understanding, "stated that evaluation is a decision-making process using information obtained through measurement of learning outcomes, using both test and non-test instruments" [3]. In general, it can be said that evaluation is giving mark on a quality of something. Apart from that Evaluation can also be viewed as a process of planning, obtaining and providing information that is needed to make decision alternatives. Evaluation is a systematic process for determining or making decisions to how far teaching objectives have been achieved by students. Furthermore, "revealed that the Evaluation is a series of activities aimed at measuring the success of educational programs" [4]. More review 
understanding of Program Evaluation in the context of the goal is as a process of assessing to which educational objectives can be achieved [5].

Psychology's dictionary, Character can be seen from an ethical or moral point of view, such as a person's honesty, and is usually associated with relatively fixed traits. In www.gurupendidikan.com (2013) some experts explain the character, Lickona explains character education can be defined as every effort must be made to influence students'character, Suyanto defines the character as a way of thinking and behaving is a way of each individual to live and work together, within the family, society, nation, and country. Based on some descriptions about the character and opinions of some experts above, can be infered that the character is an important thing to shape one's attitude. For the school environment, the arrangement and improvement of the existing curriculum needs to be done, so that Indonesian can be aligned with otherdeveloped nations in the future. To be able to identify the character Suyadi (2013) explains that the Ministry of National Education has set 18 character values to be implementedto the learners, applied through subjects to support the implementation of Character Education process in school. The character's values are: Religious, Honest , Tolerance, Discipline, Hard Work, Creative, Independent, Democratic, Want To Know, Spirit of Nationality, Love the Country, Appreciate, Friendship / Communicative, Love Peace, Reading Fond, Care for the Environment, Social Care, Responsibility. Then In 2017 Presidential Regulation No. 87 of 2017 stated on Strengthening Character Education (KDP), at the same time the Ministry of Education and Culture formulated the concept of character education. At least, there are five main characters that want to be implanted to the students, especially on the level of elementary and junior high school that is Religious, Nationalism, Integrity, Independent and Mutual Coorporation.

\section{METHOD}

This research is an Evaluative research with Goal Free Evaluation model, it was done by assessing the process of implementation, we hope it can be used as the input in Character Education at Junior and MTs high schools in Payakumbuh. The determination of the success could be seen through the achievements of several processes, namely: The process of implementing Character Education by teachers towards students through subjects; The process of controlling attitudes and behaviors by parents through the book "Pendidikan Akhlak Mulia" in students' daily life .

In this study the population is, the entire junior and MTs high schools in Payakumbuh. The sample was taken from selected schools randomly. The types of data needed are primary and secondary in accordance with the needs of the analysis, the sources of data are, Teachers, Principals and Parents. Techniques of collecting data are documentation and survey by using questionnaires, required documents in the form of Rencana Pelaksanaan Pembelajaran (RPP) which made by the teacher for the learning process, the results of recording program Pendidikan Akhlak Mulia conducted by parents.

\section{RESULT}

Based on the sampling technique done, from the existing population there are 24 Junior High School and MTs in Payakumbuhand only $50 \%$ is taken as the population, there are 10 SMPs and 2 MTs. The source of information needed, are 6 teachers who teach in 6 different subjects at each school, Religion, IPS, Bahasa Indonesia, Penjasorkes, PPKN and Cultural Art. While the source information about the implementation of character education in daily life of the students, are their own parents whose children studyat the selected schools. There are 4 students each sample school. Then the questionnaire was also given to the Principal whose school was selected as a sample, to obtain information about the character education program in his school.

Character education program is taken from the average questionnaires score whichobtained by teachers and principals, with the highest average score that can be obtained by 120 . The highest average score is 107 obtained by MTsN Payakumbuh, followed by Islamic Junior High School RaudatulJannah 102 and SMP Negeri 8 Payakumbuh 88.0. While the lowest score are SMP Negeri 3 Payakumbuh with the score 70, followed by SMP Negeri 5 with the score 75.3 and SMP Negeri 6 with thevscore 76.4. The data can also be seen in graph 1 .

Pendidikan Akhlak Mulia Program is taken from the average score obtained by parents whose children go to junior or MTs high school in Payakumbuh. The highest score obtained by parents whose child isstudying at SMP Negeri 4 Payakumbuh with the score 82, followed by parents whose childisstudyingat Junior High School 6 with the score 78, and two parents whose children are studying at SMP Negeri 4 with the score 74 each, while the lowest score obtained by parents whose child is studying at junior high school 7 with the score 36 , followed by parents whose child is studying at junior high school 5 with the score 42, and parents whose child is studying at junior high school 6 with the score 45 .

Character education program conducted on subjects is given to subject's teachers and principals as a manager of school management, the data obtained are as shown in Table 4.3. the following. The highest percentage of character education programs were integrated through Indonesian subjects by $56.67 \%$ followed by subjects of PPKN of $52.82 \%$ and Religious Education by $43.63 \%$. While the lowest percentage of subjects obtained Penjas $31.66 \%$, followed by Art Culture of $33.85 \%$ and IPS of $40.45 \%$. While the character education program implemented through the principal's policy management obtained achievement of $52.02 \%$. 


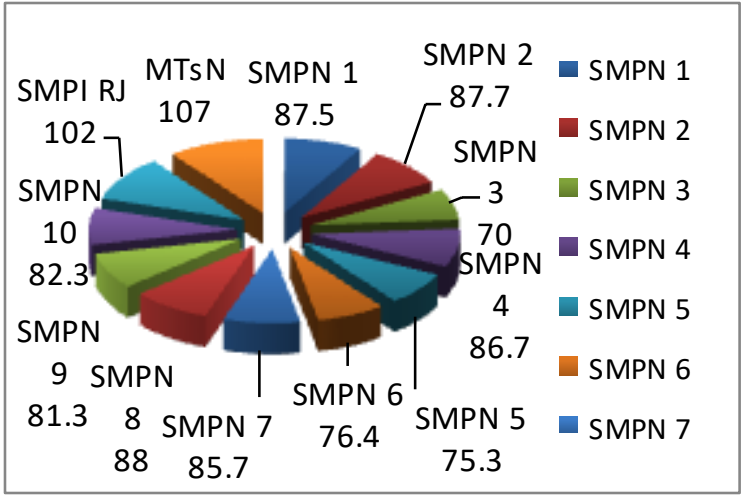

Figure 1. Average score obtained by JHS and MTs in caracter education implementation in Payakumbuh City.

\section{Analysis Result}

Based on the data found as already mentioned above, after verification and analysis of data, it can be explained the results of the analysis as follows:

The achievement of Character Educational Program conducted by teachers in each subject at SMP and MTs N Payakumbuh was obtained 44, 19\%; Achievement of students'attitude and behaviorwhich observed by parents at home and neighborhoodwas obtained 51.44\%; Through correlation analysis of the implementation of character education program through subjects with attitudes and behavior of students, parental control, obtained $r_{x y}$ of 0.20 . If we compare with the critical price, the relationship is not significant at $1 \%$ and $5 \%$, since $\mathrm{r}_{\mathrm{xy}}$ is less than $\mathrm{r}_{\text {tabel}}$, where $\mathrm{r}_{\text {table }}$ for $1 \%$ is 0.436 and for $5 \%$ is 0.339 .

With no significant correlation between character education programs in school with the attitude and behavior of students at home, with the coefficient of determination obtained contribution of influence of character education through subjects to attitudes and behavior of students who observed parents at home only $3.90 \%$.

\section{Discussion}

Character Educational Program has been created in RPP of several related subjects. It has been implemented by the teachersin the their subjects during the learning process. Nevertheless, the resultis not satisfied yet, it is not easy for teachers to integrate character education in their learning process, the limited time, the amount of material, and the task of instructional administration required by the teacher might be the cause of the low achievement. But of course this process must be done continuously, so that students'character will become better and better; Pendidikan Akhlak Mulia Program is designed by Education Department in Payakumbuh City, to synchronize between character education at school with attitude and morals at home, unfortunately it has not shown maximum results yet. It indicates that parents have not maximally controlled and directed their children base on the book of Pendidikan Akhlak Mulia that they hold, may be they have lack of time to pay attention to the children, busy working, lack of communication between children and parents. Because parents are the main pillar of character education, so that the attention and seriousness of parents are a must in shaping the character of good children. Itwill really improve by having a strong commitment; The contribution of the character education program which has been done through the subjects at school, while the children's attitude and behavior daily in the family, do not make any significant influences. It means that there is a disconnection, or something that does not connect, between what the students are doing in school and at home. This can happen due to lack of parental control, lack of communication with the children, lack of freedom to play, socialize and use something, how the teachers control the students are not the same as how the teacherscontrol them at school, so that once children get out of school control, they are free and tends wild without controling.

\section{CONCLUSION}

Based on the results of data analysis obtained and discussion, it can be concluded some conclusions as follows: (1) The achievement of the Character Education Program conducted by teachers in each subject was obtained 44, 19\%. (2) Achievement of attitudes and behavior of students through the book Program PendidikanAkhlakMulia, observed by parents at home obtained $51.44 \%$. (3) Correlation of character education programs through subjects with attitudes and behaviors of students was not significant, because obtained $r_{x y}$ by 0.20 because $r_{\text {tabel }}$ for $1 \%$ is 0.436 and for $5 \%$ is 0.339 . Through the coefficient of determination was obtained contribution of $3.90 \%$.

Some suggestions and recommendations that can be given : Establishing regulation of character education implementation by teachers through their subjects in learning process; Giving more attention to character education both in school and neighborhood on a regular and ongoing basis; Establishing a memorandum of understanding $(\mathrm{MoU})$ or cooperation agreement with parents about the comitmentof character education at school and with the students' family; Increasing the role, willingness, participation and commitment of parents in controlling and strengthening the children's character; Developing the book of Pendidikan Akhlak Muliabecomes a controlling book for Attitudes, Behavior and Extra curricular activity outside school by parents and/or Community Leaders.

\section{REFERENCES}

[1] Stufflebeam, D.L, Foley, W.J. Gephaat, W.J Guba, E.G. Hammand R.L, Marimen, "Educational Evaluation and Decision Making." Peacock; H.O \& Provus. 1971

[2] Kumano, Y, "Authentic Assessment and Portfolio Assessment-Its Theory and Practice," Japan; Shizuoka University. 2001

[3] Zainul \& Nasution, "Penilaian Hasil belajar," Jakarta; Dirjen Dikti, pp, 75-90. 2001.

[4] Arikunto, S \& Jabar, "Evaluasi Program Pendidikan," Jakarta; Bumi Aksara, pp, 67-75. 2004 
[5] Tayibnapis, Farida Yusuf, "Evaluasi Program," Jakarta; Rineka Cipta. 2000.

[6] Kemendikbud, "Peraturan Pemerintah No. 32 Tahun 2013 tentang Perubahan Standar Nasional Pendidikan,” Jakarta; Kemendikbud. 2013 